\title{
魅力と不満の要因・影響分析のための因果モデル
}

\author{
- 環境心理評価構造における統計的因果分析 その 3 -

\section{CAUSAL MODEL FOR ANALYZING CAUSES AND EFFECTS OF ATTRACTIVENESS AND DISSATISFACTION}

- Causality analysis on environmental evaluation Part 3 -

小島隆矢 ${ }^{*}$, 若林直子**, 讃井 純一郎***

Takaya KOJIMA, Naoko WAKABAYASHI and Junichiro SANUI

In this study, the method to analyzing causes and effects of "attractiveness" and "dissatisfaction" to environment was proposed. The outline of the proposed method is as follows.

1) In the survey, it is necessary to evaluate "attractiveness" and "dissatisfaction" as different items.

2) In the analysis by SEM, these two items are used as intermediate variables which explain causal effect from evaluation items of each viewpoint to comprehensive evaluation.

The proposed method was applied to the three survey cases "regional environment","public facility" and "large-scale park", several findings on the methodology of survey and analysis were obtained.

Keywords : Attructive quality, Must-be quality, Structural Equation Modeling, evaluation structure, latent variable 魅力的品質, 当たり前品質, 構造方程式モデリング, 評価構造, 潜在変数

\section{1. はじめに}

本研究では，環境心理評価項目間の因果関係を扱う手法や理論に関 する知見を得ることを目的とした検討を行っている。

既報 ${ }^{12)}$ では，実際の評価データを用い，讃井他 ${ }^{3) 4}$ )による「階層構 造モデル」の仮定を実証した。また, グラフィカルモデリング（以下， GM と略記）による候補モデル探索の後, 構造方程式モデリング（以 下，SEM）によりモデル選択・検証・微修正を行う連携技法を提案し た。評価グリッド法 (EGM) に基づく項目設計を含めた連携戦略は, 後に「EGM $\rightarrow \mathrm{GM} \rightarrow \mathrm{SEM}$ 作戦 ${ }^{5)}$ と呼ばれるようになった。

この種の因果モデルは，個別の観点の評価（以下，「個別評価」と 記す）を原因系, 価值判断や意思決定に関わる総合的な評価（以下, 「総合評価」と記す）を結果系とする。本報では，総合評価の直前に 総合的な「魅力」と「不満」の度合いを表す中間変数を設けることに より, 個別評価を「魅力要因」「不満要因」に仕分け, また, 総合評 価に対する「魅力」「不満」の影響を比較できる手法を提案する。

\section{2. 本論文の目的および構成}

本報の目的は，まず第一に，前述の着想に基づく分析により，魅力 と不満の要因および影響を把握できることを示すことである。さらに, 適用事例の検討を通して, 分析手法上の知見, 魅力と不満の要因・影 響に関する評価構造上の知見を得ることを目的とする。
本論文の構成を述べる。この後の 3 章では，本手法の背景となる既 往研究および本手法の意義について論じる。4 章では, 研究方法とし て, 手法の概要と検討課題を述べる。 5 章では, 最初の事例を用いて 基本的な分析技法を検討しつつ, 本手法によって魅力と不満の要因・ 影響が把握可能であることを示す。6 章と 7 章では, その他の事例の 分析結果を示す。 8 章では, 各事例の分析結果をもとに総合的考察を 加える。最後に 9 章では成果を総括し今後の課題と展望を述べる。

\section{3. 既往研究}

讃井ほか ${ }^{3)}$ には，環境評価を「各人が心の中に設定した目標の達成 度合い」とする Canter $^{6)}$ の定義に関する言及がある。久野 ${ }^{7)}$ は, 「完 全な満足に足りない度合い」測定のため, 不満の程度を測定する片側 尺度を提案しており，これは Canterの定義と同主旨といえる。

しかしながら Canter の定義では，「積極的な満足（「期待（目標） 以上の満足」や「思いがけない満足」)」を表現できない。久野 ${ }^{7)}$ は当 時の都市環境悪化を背景するため不満測定は合目的的である。一方, 讃井ほか ${ }^{3)}$ はニーズの構造と評価の構造の一致を論証する部分に Canter の定義を用いているが，評価グリッド法の意義はむしろ積極 的満足の追求にある。讃井 ${ }^{8}$ には, 『基本機能の充実や不便・不満の 解消といった共通性の高いニーズへの対応という課題に対しては従 来の「標準人間モデル」や「設計者自身の経験によるニーズ想定」が

\footnotetext{
* 早稲田大学人間科学学術院 教授 · 博士 (工学)

** (秼)生活環境工房あくと 代表・博士 (工学)

$* * *$ 関東学院大学人間共生学部 教授. 工博
}

Prof., Faculty of Human Sciences, Waseda University, Dr. Eng. Representative Director, Living environment studio act, Dr. Eng. Prof., College of Interhuman Symbiotic Studies, Kanto Gakuin University, Dr. Eng. 
有効であるが,「プラス $\alpha$ の魅力（積極的満足）」は個人差が大きいた め新しい方法論が必要であった。という主旨の記述がある。

不満がない状態と積極的な満足の区別に関わる研究としては, 職務 満足に関する「動機づけ衛生理論 $\left(\right.$ Herzberg $\left.\left.^{9)}\right)\right\rfloor$, および品質分野の 「魅力的品質と当たり前品質 $\left(\right.$ 狩野他 $\left.{ }^{10)}\right) 」 か ゙$ 知られる。

北垣 ${ }^{11)}$ によれば Herzberg は約 200 名の技師・会計士に，まず「職 務に満足した時期/不満を感じた時期」の想起, 続いて「そう感じた理 由・内容」「その感情による影響」等を問う半構造化インタビューを 行った。そして満足要因である仕事内容, 達成感などを「動機づけ要 因」, 不満要因である職場環境, 給与, 待遇などを「衛生要因」と命 名し, 後者の充足だけではモチベーションは向上しないと主張する。 狩野他 ${ }^{10)}$ は, この理論を商品の企画開発等になじむようアレンジし, 次のような品質要素の分類法を提案した (Fig.1 も参照)。

\begin{tabular}{|l}
\hline ・当たり前品質 : それが充足されても「当たり前」としか受けと \\
られないが (評価は上がらない), 不充足であれば不満を引き起 \\
こす (評価が下がる) 品質要素。 \\
・一元的品質 : それが充足されれば満足を与え（評価が上がる), \\
不充足であれば不満を引き起こす（評価が下がる）品質要素。 \\
・魅力的品質 : それが充足されれば満足を与えるが（評価が上が \\
る), 不充足であっても「しかたない」と受けとられる（評価は \\
下がらない）品質要素。
\end{tabular}

さらに, 各品質要素について「もしよかったならば」「もし悪かっ たならば」どう思うかを，「気に入る／当然である／何とも感じない /しかたない／気に入らない／その他」から選択寸るという調査法を， ヒット商品（置き時計）の企画実例とともに報告している。

Herzberg と狩野には, 「満足」「不満」の捉え方に若干の違いがあ る。前者における「満足」「不満」は要因・影響が異なることから， それぞれを別個の構成概念と考える方が自然であろう。一方，後者

（Fig.1）の「満足」「不満」は満足感という 1 つの概念の高い状態と 低い状態を表しており, 品質分類は主観的評価（満足感）に対する物 理的充足状況の要因効果の関数形によって定義される。

Herzberg・狩野に関わる建築分野の研究もいくつかみられる。まず, Herzberg 同様に, 自由記述の内容を満足側と不満側に分けて解採す る研究に, 古賀・小島他 ${ }^{12)}$, 小島・若林 ${ }^{13}$ 注2) がある。前者は「キャ プション評価法」による景観調查，後者は地域の「魅力」「不満」を 答える自由記述式設問の事例である。狩野の調查法を用いた研究とし ては, 高・小島他 ${ }^{14)}$ による住宅と大学院生室に関寸る調查ほか, 数件 の事例が報告されている。

ところで，狩野の調查法における物理的充足状況は質問文により想 定させているにすぎない。実際に評価データの要因効果に基づき品質 分類を行っている建築学研究は, 個別尺度法 ${ }^{15)}$ を用いた彭・小島 ${ }^{16)}$ が唯一の事例である。しかし個別尺度法の標本サイズの限界から，そ の要因効果は各個別尺度ごとの一元配置モデルによる。すると他の尺 度の要因効果も交絡するため，本来は多要因モデルが望ましい。

彭・小島 ${ }^{16)}$ は, 品質分類の意義について『「当たり前品質」は不満 解消や基本性能の充実,「魅力的品質」は付加価值の追求や設計コン セプトの検討に関わる概念であり，実学的に異なる意味合いを持つ。」 と述べている。ここで下線部の内容を考えると, まず, 設計において 当たり前品質に関する設計目標は「不満がない状態」であるから，初 期コスト・維持コストの増加を招く過剩品質を回避すべきである。一
方, 魅力的品質は個人差が大きいため（前述の讃井 ${ }^{8)}$ ), 回避すべき は「ニーズと設計のミスマッチ」である。当該環境の利用者ニーズを 特定し，設計コンセプトを策定することが必要となる。

小島 ${ }^{17)}$ は, 環境づくり活動における魅力要因の効用について「音景 色のために, 騷音を減らそう」というサウンドスケープ活動を例に, 「不満や不安の解消を目標とする活動はモチベーションを保ちにく い。何らか魅力的品質の充足を目標として, その達成のために不満解 消も図られる，という戦略が上策」と論じている。この論点は狩野よ りむしろ Herzberg の「動機づけ」という部分に関連する。

ここまでの議論を若干の補足考察を加えつつ, 以下にまとめる。

・環境評価において「不満がない状態」と「積極的な満足・魅力」を 区別する理論・方法が必要である。

・先行研究に Herzberg ${ }^{9)}$, 狩野他 ${ }^{10)}$ がある。前者は「満足」「不満」 を別の構成概念と捉え, 後者は満足感に対する要因効果の関数形か ら「満足」「不満」の要因を区別する。

・調查分析の方法として, Herzberg ${ }^{9}{ }^{9}$ に類する定性調查と，「よい状 態」「悪い状態」の想定質問による狩野他 ${ }^{10)}$ の質問紙調查がある。

・建築分野の適用事例もいくつかあるが，実際の評価データから「不 満がない状態」「積極的な満足」の区別を実現している満足できる 事例はみつからない。

・不満解消と積極的な満足・魅力の追求では, 設計における位置づけ が異なる。また，環境づくりにおいては，後者（魅力創造）を目標 とした活動の中で前者（不満解消）を考えるのが上策である。これ ら観点から，建築学において「不満」「魅力」を区別することには 実学的意義がある。

\section{4. 研究の方法}

\section{1 提案する手法の概要および検討課題}

提案手法の測定部分は，一般的な CS（顧客満足度）調查 ${ }^{2}$ (注におい て, 対象を評価する項目として,「個別評価」「総合評価」に加えて, 以下に例示する $2 つ$ 評価項目を追加した調査を行うだけでよい。

・魅力度 : (不満はさておき) 魅力が，大いにある〜全くない

・不満度：(魅力はさておき) 不満が，大いにある〜全くない

選択肢は久野 ${ }^{7)}$ の片側尺度を参考としている。魅力度は前章の「(積 極的な）満足」に相当するが，「満足」という語句を使うと単なる「不 満」の反対語と受けとられることを危惧して「魅力」に置き換えた。 括弧内の補足は実際の調査ではもう少し詳しく書く。以下，このワー ディングにあわせて本文中では「(積極的な) 満足」の意味で「魅力」 を用いる。また, 概念および潜在変数の場合は単に「魅力」「不満」, 観測変数に対しては「魅力度」「不満度」と表記して区別する。

なお，一般的な個別評価，総合評価（上記 2 項目とは別に）を測定 していることは前提である。Fig.2 のように個別評価から総合評価へ

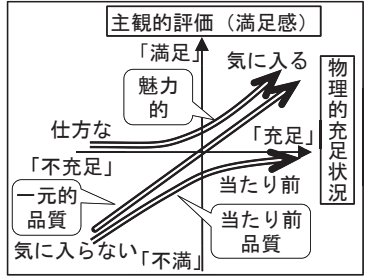

Fig.1 Concept of

Kano's method ${ }^{*}$ Redrawn baseed on Kano et al. ${ }^{10}$

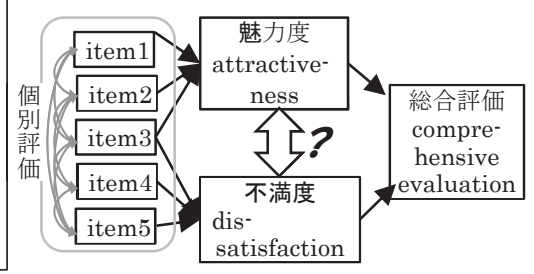

Fig.2 Causal model for the basic idea 
の全ての影響を「魅力度」「不満度」を経由する間接効果として表す モデルとすることが基本的アイディアである。

本手法において「魅力」「不満」は異なる構成概念であり, 要因（= 魅力/不満に影響する個別評価)および影響 (二魅力/不満から総合評価 へのパス係数）の違いを把握しようとする点は Herzbergに近い。ま た，狩野の方法による調査の多くは，「よい状態」「悪い状態」の想定 質問のほか，実際に使用や居住をしている対象の評価も行うため，合 計質問数は評価項目 (品質要素) の 3 倍となる。本手法の場合, たつ た 2 項目の追加で済むことは大きな利点である。

実際の分析においては, 「魅力度」「不満度」が単なる反対語でなく 別概念として評価されるか, 変数選択や候補モデル探索の方法, 特に 「魅力度」「不満度」間の関係（Fig.1 の”?”), 評価の階層性の取り 入れ方, 総合評価が複数ある場合の扱い方, など様々な検討が必要で ある。本報では,「地域」「官庁施設」「公園」を評価対象とする 3 つ の調查事例を用いて, これら課題を検討する。

\section{2 調査事例の概要}

本報の調査事例は, 必ずしも提案する手法の検討を行うことを第一 の目的として実施されたものではない。実際の経緯としては, 各事例 ごとに学術的や実務的な背景と要求があり, その要求に対して本手法 が有効と思われる場合に本手法を採用したものである。検討要因以外 は条件を揃えて比較する実験研究のように適用事例を計画する方法 が望ましいという見解もありうるが，実学的要請に応えるための実践 的適用を通して方法論上の課題を検討し完成度を高めるという方法 も, 有用な研究成果を生み出す手法研究のあり方の一つと考える。

各調查は約 5 年間の間にこの順に実施しており, 項目設計は実施済 み事例の経験をふまえて順次改良を試みている。そこで調査項目につ いては次章以降の各事例の分析部分の冒頭にて報告することとし, こ こでは背景・要求などを中心に各事例の調査概要を述べる。

\section{事例 1 :「地域」に関する住民意識調査}

本手法の最初の適用事例となった調查であり，2003 年 12 月〜翌 1 月に実施したインターネット調査である。地域関与に関する調査項目 検討注 4)を主目的とする構成であるが, その一部を本手法適用のため 居住地域を評価する設問にあてている。1995 年の阪神大震災, 2000 年代前半の犯罪不安増大を背景として, 防災・防犯が地域環境づくり の課題として重視された時代であったが,「不安や不満の解消ではな く魅力創造を目標とする活動が上策 (小島 ${ }^{17)}$ ) 」という視点から, 魅 力・不満の要因・影響を把握することも目的であった。回答者は首都 圈 (一都三県) 在住の調查会社モニター登録者より性別・年齢 $(20 \sim 29$ 歳/30 39 歳/40〜 59 歳) ごとに計画し, 有効回答 654 件となった。

\section{事例 2：「官庁施設」に関する職員のCS 調査}

本事例は, 国交省営繥部における公共施設 CS 調査の一環として 2004 年に実施した調查の一部を抜粋して用いる。調查の目的・経緯, 項目設計, 実施様態などは小島他 ${ }^{19)}$ を参照されたい。

この調查は建築・建替え等が行われた施設について, 供用開始後 1 年以上経過した時点で行われる。本報では特殊用途 (裁判所, 研究所, 保安関連など）を除き，空口業務や一般事務を主体とする 16 施設 (合 同庁舎, 職業安定所など）の職員を対象とするデータを用いる。有効 回答 827 件である。内容的にはほぼオフィス満足度調查ともいえる。

小島 ${ }^{17)}$ は公共施設（官庁施設）の評価について,「(予算源が税金で あることから注 5) $)$ 的外れの過剩品質に陥ってはならない」「(民間の
建築の範として誘導する役割も担うため注 5)）単に用が足る以上の魅 力や価值を追求寸ることもまた, 求められている」と論じている。こ れら問題を考える上で「不満」「魅力」の区別は有用である。

\section{事例 3 ：「公園」に関するアンケート調查}

本調查は静岡県浜松市の 2 つの大規模公園 : 浜名湖ガーデンパーク （以下「浜名」）と佐鳴湖公園（以下「佐鳴」）を対象に 2008 年 10〜 12 月に実施した。「浜名」は浜名湖の埋立て造成農地を整備して 2004 年に開催された「浜名湖花博」跡地をさらに再整備し, 翌 2005 年に 開園した公園である。この新しい公園に対する利用者・市民の評価を 知ることが本調查の主眼である。「佐鳴」は「浜名」の比較対象とし て選んだ古くからある大公園であり, 同じく浜松市の湖に面する。

両公園の周辺住民一の郵送調查と「浜名」利用者に対する現地調查 を併用して行い注 6), 「浜名」531 件, 「佐鳴」422 件, 計 953 件の評 価データを得た。分析には使用変数に欠測のない 816 件を用いる。

\section{3つの事例の位置づけ}

前述のように各事例は手法研究のために計画実施したものではな いが，結果的に手法検討を行う上で好ましいバリエーションとなった。 まず, 事例 1 は住環境, 事例 2 は働く環境, 事例 3 は余暇に利用する 環境（住環境の一部ともいえるが）を対象とする。環境と評価者の抽 出方法の点では, 事例 1 は環境を評価者とともに無作為抽出する形, 事例 2 は 16 施設とその職員という 2 段階抽出, 事例 3 は特定のごく 少数個の環境を評価対象とする形の事例である。

これら事例間の相違により, 測定・分析技法や把握される因果構造 に違いはあるか，という視点を持ちつつ，各事例の分析を行う。

\section{5.「地域」に関する住民意識調査の分析【事例 1】 \\ 5. 1 調査項目【事例 1】}

分析対象項目を Table1 に示寸。個別評価には階層性があり, X1 11 が下位, Y12 15 が上位項目である。Z16 17 は魅力/不満度, T18 21 は総合評価である。魅力/不満度以外は全て 5 段階両極尺度であり, 既 報 ${ }^{112)}$ の地域環境評価の事例, 武藤他 ${ }^{20)}$ を参考に設計注7) した。設問の 順序は, 総合評価 $\rightarrow$ 個別評価（上位と下位は混在）－魅力/不満度の順 であり，その都度新しい画面で回答する形式としている。

魅力/不満度の質問文・選択肢は下記の通り（[ ] 内はいずれか)。

あなたがこのまちに対して感じる[魅力/不満]は，どの程度ですか。 [不満な点には目をつぶっていいところはさておき], [魅力/不満] に感じている点だけを考え，その大きさを評価してください。

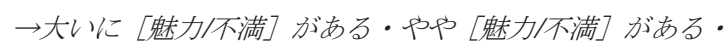

あまり[魅力/不満]はない・まったく[魅力/不満]はない

分析においては, 魅力/不満度は, 全くない(1)〜大いにある(4), そ の他の項目は，好ましくない側(1)～好ましい側(5) と得点化する。

最初から階層性を導入したモデルとするのは難しいので, まず下位 項目のみを個別評価として用いて分析を進め, 良好なモデルを得た後 に上位項目の追加を考えることとする。

\section{2 予備的分析【事例 1】}

魅力/不満度の単純集計の結果は, 「全くない」側から順に, 魅力度 が $3.7 \% \cdot 20.8 \% \cdot 60.2 \% \cdot 15.3 \%$ (平均=2.87, 標準偏差=.70), 不満 度が $2.6 \% \cdot 39.4 \% \cdot 47.9 \% \cdot 10.1 \%$ （平均=2.65, 標準偏差=.69） と なった。「全くない」が小頻度で, 分散も大きくない。測定信頼性の 低さが懸念される。両者の相関係数は-.331 であり, 絶対值は大きく 
ない。単なる反対語ではなく別概念として評価されていることがわか る。他の項目の標準偏差は, 若干小さい X1（.74）を除き, 0.9 弱 1.2 台と十分であり，分布形にも大きな問題はみられなかった。

事前分析として, 個別評価 (下位項目) を説明変数, 満足/不満度と 総合評価を目的変数としてステップワイズ式の重回帰分析を行った。 p<.05 .10 を目安とした変数選択の結果を Table2 に示す。どの目的 変数に対しても選択されないX11（歴史・情緒）は不採用とし，いず れかに有意な効果があるX1 10 を個別評価として SEM に用いる。

\section{3 初期モデルによるパス解析【事例 1】}

初期モデルとしては「個別評価一魅力/不満度」のパスを全て設け， 魅力度と不満度の間には誤差相関を設ける。総合評価は 4 項目あるが, 1 項目ずつ用いる 4 つのモデルと，4 項目を同時に用いるモデルを試 みる。後者においては各総合評価は魅力/不満度からのパスを受け, そ れらの間には全て誤差相関を設ける (小野・小島 $\left.{ }^{21 \text { 注 }}{ }^{8)}\right)$ 。

計 5 通りのモデルの分析結果は, 有意なパス係数の符号（不満度に 対して負, 魅力度に対して正）はいずれも内容的に妥当であった。し かし適合度の点では, 総合評価 1 項目のモデルは RMSEA=.088〜.108, 4 項目のモデルは RMSEA=.065 と,「非常に良好」とはいえない。非 有意パスを削除して自由度節約・適合度改善を試みたが，良好とされ る RMSEA $\leqq .05$ のモデルは得られなかった。

適合度不足の原因は, 前節にて懸念された魅力/不満度の測定信頼性 の低さにあると予想した。この予想が正しいとすれば, 魅力/不満度の 潜在変数化が有効である(そのしくみについては「付録」を参照され たい)。節をあらためてこの方針によりモデル改善を試みる。

\section{4 魅力/不満を潜在変数化した因果モデルの分析【事例 1】}

中間変数である魅力/不満度を潜在変数化した「魅力」「不満」を用 いるモデルを考える。モデル安定性の点で潜在変数からパスを受ける 観測変数は複数ある方がよいので, 総合評価は全て同時に用いる。

まず 5.3 節同様に,「下位項目 $\rightarrow$ 魅力/不満」の全てのパス, 魅力-不 満の間と各総合評価間に誤差相関を設けた初期モデルにより SEM を 実行すると，RMSEA=.041 と適合のよいモデルが得られた。

その後，次のような手順で採用モデルを確定した。

1）符号が妥当でないパス，非有意なパスを順次，削除する。

2）魅力/不満の原因系が異なる構造となった後, 魅力-不満の間をいず
比較する。その結果, 「魅力 $\rightarrow$ 不満」の向きのパスを採用した。 3）非有意パスを適合度の許容範囲内で削除し，モデルを確定する。

得られたモデルを Fig.3 に示す。適合度は非常によい。魅力/不満度 の信頼性（ここでは決定係数）は魅力度が.78, 不満度が.39 と推定さ れる。不満度の信頼性はかなり低い。これが真值と測定值を分離しな いモデルにおける適合度低下を招くのであろう。

\section{5 因果モデルに基づく考察【事例 1】}

得られたモデルが表す因果関係について考察を加える。まず，魅力 /不満へのつながりから，下位項目を次のように分類できる。

・魅力にだけパスがある（魅力要因／魅力的品質）

‥「きれい」「自然」「景観」「交流活発」

・魅力/不満の双方にパスがある（魅力と不満の要因／一元的品質）

…「生活施設」「交通・買い物」「近所づきあい」

・不満にだけパスがある（不満要因／当たり前品質）

…「災害安全」「事故犯罪」「騒音振動」

環境の豊かさに関わる項目は「魅力的」, 利便性に関わる項目は「一 元的」, 安全・衛生に関わる項目は「当たり前」に分類され, 内容的 に妥当と感じられる。「近所づきあい」から魅力へのパス係数は 0 に 近いので，「当たり前」に分類してもよいかもしれない。「交流活発」 は「魅力的」であるから，近隣交流に関わる項目は全体的には「一元 的（魅力にも不満にも関わる）」ともいえる。

魅力-不満の間には「魅力 $\rightarrow$ 不満」の負のパスがある。逆向きのパス も追加したモデルにおいても,「魅力 $\rightarrow$ 不満」の標準化パス係数は-.207 で有意 $(p<.05)$, 「不満 $\rightarrow$ 魅力」は-.078 で非有意となる。つまり, 魅 力は不満を下げるが，不満は魅力に影響しない。

魅力/不満から総合評価への影響を比較すると, 標準化パス係数の絶 対值は, 総じて魅力の方が不満より大きい。特に「愛着」は差が大き い。「住み続ける」のみ差が小さいが，「魅力ー不満」のパスのため間 接効果が生じ,「住み続ける」においても標準化総合効果は不満から -.39, 魅力から.49 となる。地域環境に対して居住者は, 不満より少 し魅力を重視して総合評価していることを示唆する結果である。

\section{6 階層構造を導入した因果モデルの分析【事例 1】}

次に, 因果モデルに上位項目を追加し，個別評価部分の階層化をは かる。分析結果を Fig.4 に示す。以下，分析過程を概説する。

Table2 Result of Multiple Regression Analysis [case1]

Table1 Evaluation item of case1:survey for regional environment No 項目名 : Item name 実際のワーディング(wording) X1 災害安全:disaster safety 地震などの災害に対し, 安全-危険

X2 事故犯罪:accidents/crime 事故や犯罪などに対し, 安全-危険

X3 騒音振動:noise 騒音や振動が，気にならない-気になる

X4 近所づきあい:neighborhood 近所づきあいに, 満足-不満

X5 交流活発:communication 地域の人々の交流が, 活発-希薄

X6 生活施設:facilities satisfaction

生活に便利な施設などが，充実している-充実していない

X7 交通·買い物:traffic/shopping 通勤通学や買い物などに,便利-不便

X8 きれい:clean 空気や路上などが，きれい-污い

X9 自然: green/water 緑や水など自然に親しめる-親しめない

X10 景観:townscape＼cjkstart景観がよい-景観がわるい

X11 歴史・情緒:history＼cjkstart歴史や情緒がある-歴史や情緒がない

Y12 安全:safety このまちは, 安全-危険

Y13 便利: convenient このまちは, 便利-不便

Y14 文化的:cultural一文化的に豊かーまずしい

Y15 住環境:living environment 住環境として豊か-豊かではない

Z16 魅力度:attractiveness 大いに魅力がある-まったく魅力はない

Z17 不満度:dissatisfaction大いに不満がある-まったく不満はない

T18 住みよい:livability＼cjkstart私にとって住みよい-住みにくい

T19 好ましい:preference 好ましい(好き)-好ましくない(嫌い)

T20 愛着:attachment このまちに愛着がある-愛着がない

T21 住み続ける:intention to keep living

できるなら，住み続けたい-引つ越したい

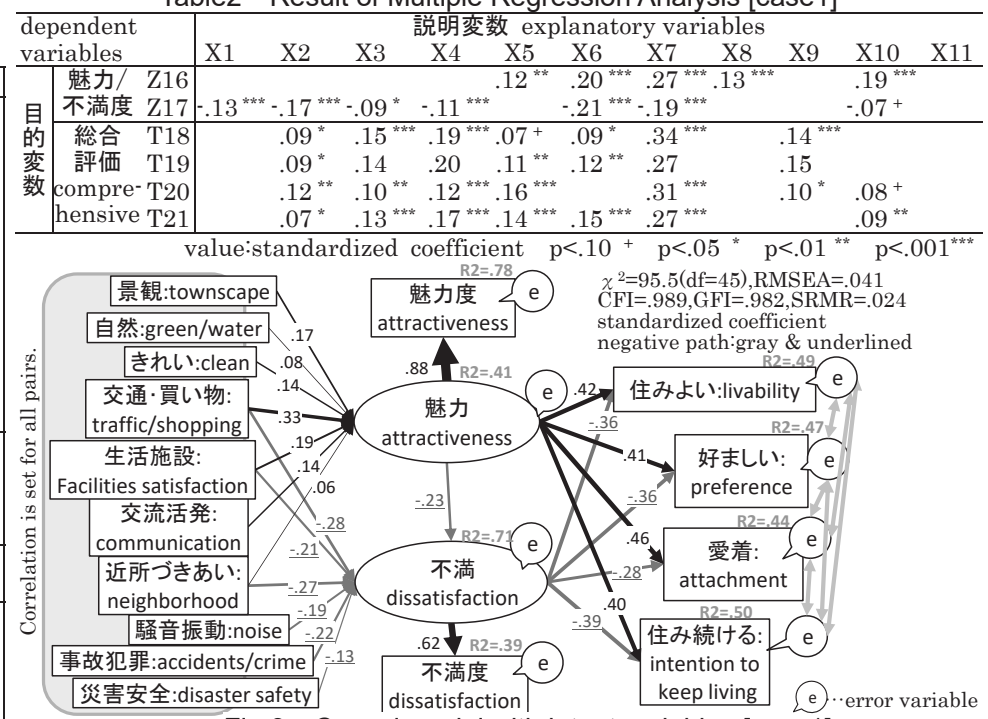

Fig.3 Causal model with latent variables [case1] 
まず階層構造部分を同定するため，個別評価（下位 X1 10 と上位 $\mathrm{Y} 12$ 15) を対象に, 連鎖独立グラフの $\mathrm{GM}^{2)}$ ) による候補モデル導出, SEM による候補モデルの比較を行い, 上位項目間を 便利 $\rightarrow$ 文化的 $\rightarrow$ 住環境—安全という関係とするモデルを選択した。この構造を Fig.3 の個別評価部分に組み込み SEM を実行する。その際, 上位項目も中 間変数であるから，これらを潜在変数化すると「文化的一住環境（潜 在変数間)」の標準化パス係数が 0.9 を超えた。そこで両者を「環境

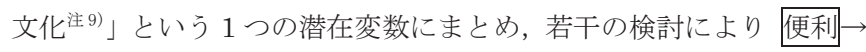
文化的の関係は潜在変数間の「利便性 $\rightarrow$ 環境文化」, 住環境〔安全 の関係は潜在変数から観測変数への「安全衛生 $\rightarrow$ 住環境」というパス で表現している。なお,「安全衛生」は観測変数「安全」を潜在変数 化した変数であるが，「騒音振動」からのパス，「住環境」へのパスを

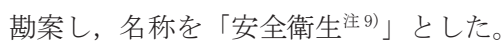

魅力/不満へのパスを適合度が低下しない範囲で絞り込むと, 下位項 目からの直接パスは「近所づきあいい不満」のみ残った。また，「自 然 利便性」にパスを設けると-.09 程度の負の係数となるが，自然に 親しめることが利便性を低下させるという因果関係は不合理注 10) と考 え，両変数間にはパスではなく（誤差）相関を設けている。

得られたモデルが Fig.4 である。 RMSEA の小数 3 桁表示は.050 で あるがわずかに 0.05 を下回っており，適合度は良好といえる。

\section{7 階層性導入モデルに基づく考察【事例 1】}

まず，上位項目（潜在変数）と魅力/不満の関係から，「安全衛生」 は不満にだけ影響するため「当たり前品質」、「環境文化」は魅力にだ け影響するため「魅力的品質」といえる。「利便性」は，一見，不満 にだけ影響するようにみえるが，魅力に対しても「環境文化」を介し て標準化効果.38（=.48×.79） と十分な大きさの間接影響があること から「一元的品質」といえる。「魅力的」「当たり前」「一元的」を代 表する概念 1 つずつという明解な構成となった。これら上位項目への パスに注目寸れば, 容易に下位項目の品質分類が可能であり，その結 果は 5.6 節の分類と一致する。「魅力/不満一総合評価」のパス係数は Fig.3 とほぼ変わらない。階層構造の導入によってモデルが表す因果 関係が大きく変化していないことを確認できる。

特に「利便性」の効果についてはかなり興味深い構造である。便利 であること自体は不満低減の効果しかないが，便利であると「環境文 化」が向上することが魅力につながる，と考察できる。若林他 ${ }^{22}$ は， 都市生活者に対する EGM 準用調查の結果から，利便性の上位概念に ついて「便利だと時空間の制約がなくなり『自由になる』『あくせく しない』『ゆったりできる』, その結果『活動的になる』」と報告して いるが，Fig.4の「環境文化」は若林他 ${ }^{22)} の 「$ 利便性上位概念」に相 当する。本事例において「環境文化」を測定している観測変数「文化 的」「住環境」だけでは利便性上位概念のニュアンスを表現しつくせ ていないであろう点は惜しまれる。例えば「活動的に生活できる」等 の観測変数を追加した場合,「文化的」「住環境」とともに潜在変数（現 「環境文化」）を共有するか，あるいは関連をもちつつ魅力につなが る別の潜在変数を形成する構造が得られることが予想される。

以上に述べた利便性に関する考察は，「環境づくりの目標を魅力創 造とするのが上策 $\left(\right.$ 小島 $\left.{ }^{17}\right)$ 」という観点に関する 1 つの成果といえ る。例えば，すでにある程度の利便性が充足されている都市部におい て，利便性自体ではなくその上位概念「環境文化」の具体的内容が今 後の環境づくりの目標となりうることを示唆する。

\section{6.「官庁施設」に関する職員のCS 調査の分析【事例 2】 6. 1 調査概要【事例 2】}

評価項目をTable3に示す。形式的には全て 5 段階両極尺度である。 設問の順序は，総合評価（T37 39）, 個別評価（X1 Y34）, 魅力/不 満度（Z35 36）と，事例 1 同様である。個別評価は空間・観点別に 設問が設置され, 各設問の最後をそれらの総合評価的な項目とする構 成（すなわち Table3 の通り）である。魅力/不満度は事例 1 をふまえ 分散確保のため片側 4 段階から両極 5 段階に変更し,「ない」側の極 を「ほとんどない」として表現を緩めた。また，事例 1 をほぼ踏襲し た質問文による評価の後, 具体的な魅力/不満を自由記述する子設問が 付随しており，自由記述を引き出す役割ももたせている。

対象 16 施設の回答者数は 8〜155 名とばらつきが大きい。欠測の多 い回答者を除外した上で, 回答者 50 名以上の 8 施設は 50 名を上限に 無作為に再抽出したデータ（計 598 件となる）を分析に用いる。

\section{2 分析結果【事例 2】}

魅力/不満度の単純集計の結果, 「ほとんどない」側から順に, 魅力 度は $4.4 \% \cdot 6.3 \% \cdot 42.4 \% \cdot 34.9 \% \cdot 12.0 \%$ (平均=3.44, 標準偏差=.94), 不満度は $18.7 \% \cdot 22.9 \% \cdot 27.2 \% \cdot 17.3 \% \cdot 13.9 \%$ （平均=2.85，標準 偏差=1.30）となった。魅力度の「ない」側が小頻度ではあるが，分 散の大きさは十分である。不満度の分布形は一様分布に近く, 分散は むしろ過大である。魅力度と不満度の相関係数は-.213 と事例 1 より さらに低く，別概念として評価されていることがわかる。

個別評価を下位項目のみを用い, 事例 1 とほぼ同様の探索過程を経 て，Fig.3 と同様のパス図概形をもつモデルを得た。分析結果として 標準化パス係数等を Table4 に示す。適合度は良好である。

魅力/不満度の信頼性（決定係数）は魅力度が.59, 不満度が.33 と推 定され, 事例 1 より少し低い。不満度は一様分布に近い分布形であっ たから，天井・床効果が生じている可能性がある。

\section{3 分析結果に基づく考察【事例 2】}

下位項目からのパスは, 結果的には魅力か不満かのいずれか一方に の夕設けられ, 魅力要因（魅力的品質）と不満要因（当たり前品質） に二分された。具体的には下記の通り。

・魅力要因 (魅力的品質)

…「会話」「照明」「内装」「駐車場」「バリアフリー」「外観印象」

・不満要因（当たり前品質）

‥「自席周り広さ」「開放感」「室内整然」「打合せコーナー」「レイア ウト変更」「玄関ホール」「施設内移動」「トイレ」「温熱感」

執務室や仕事スペースに関しては, 会話しや寸さ, 照明, 内装印象

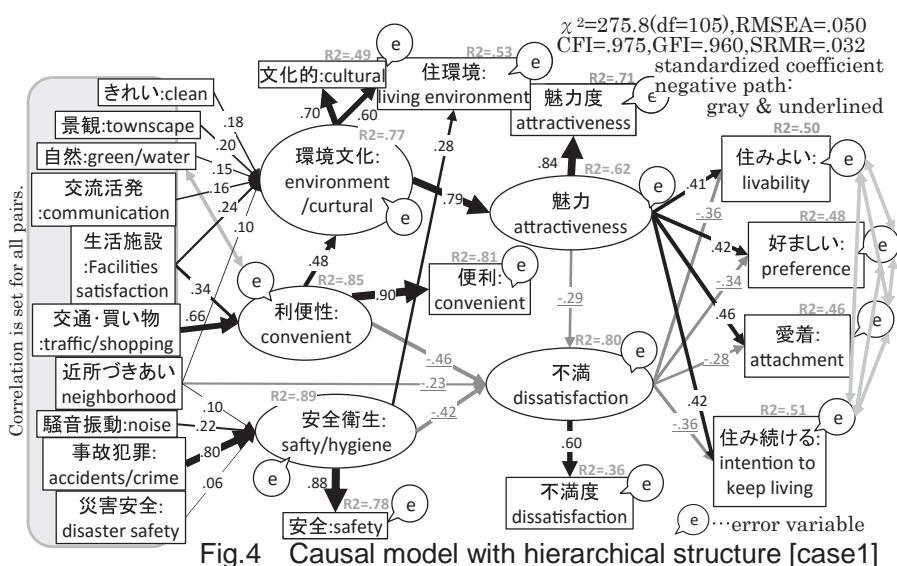


Table3 Evaluation item of survey case2: CS-survey for pablic facilities X1 自席周り広さ:personal space area 自分のデス周りは,十分に広い狭くて困っている X2 音・人目:noise/others

X3 会話しやすさ:conversation

X4 照明:light仕事上の会話が,しや寸い-しにくい 照明について,不満・不都合はない-ある X5 電源・端子:plug/terminal

Y6 自席周り総合評価:personal space (overall) 総合的にみてデ多周りは,仕事がしやすいしにくい

X7 開放感:spaciousness 開放感がある-ない X8 室内整然:orderliness 整然-雑然としている X9 内装:interior 内装の感じがよい-よくない

Y10 室内䨌囲気総合評価:office impression

総合的にみてこの執務室は,雰囲気がよいーよくない

X11 収納:storage space

X12 室内移動:movement (office)

X13 コピー等:copy/fax

X14 打合せコーナー:meeting space ・注ついて 不満・不都合はない-ある

X15 会議室:conference room

X16 来者対応: visitor support

X17 レイアウト変更: layout change …は (おそらく) 容易である-でない

Y18 仕事スペース総合評価: workspace(overall)

X19 交通 $の$ 便:traffic convenience

X20 玄関林ル:entrance …不満・不都合はない一ある

X21 迷いにくさ:wayfinding

X22 施設内移動:movement(overall facility)

施設内の移動について,不満・不都合はない-ある

X23 トイレ:toilet …不満・不都合はない-ある

X24 駐車場:parking area‥不満・不都合はない-ある

Y25 その他の空間総合評価:non-workspace(overall)

総合的にみて執務室以外 $の$ 部分は利用しや寸い-にくい

X26 温熱感:thermal

暑さや寒さについて 不快は感じない-感じることがある

X27 空気環境: air

Y28 快適性総合評価: confort

総合的にみて施設内での快適性について, 満足-不満

X29 歩行安全:walking safety

X30 バリアフリー:barrier-free

お年寄りや子供・身体が不自由な方の

利用しやすさ・安全性に,配慮されている-いない

Y31 利用者安全総合評価: user safety 総合的にみて

利用者の安全·安心に配慮されているーいない

X32 外観印象: exterior

建物の外観の印象は,好ましい一好ましくない

X33 建物周り䨌囲気: around building

Y34 地域影響総合評価: effect to area

総合的にみて仕事で使うスペースは,使いやすい-にくい総合的には地域に対し,よい影響を与えている-いない

Z35 魅力度:attractiveness 大いに魅力がある-ほとんど魅力はない

Z36 不満度:dissatisfaction 大いに不満があるーほとんど不満はない

T37 働きやすい:good workplace 働きやすい-働きにくい

T38 総合満足:overall satisfaction 総合的には 満足-不満

T39 愛着: attachment

*SEM に用いた項目および上位項目のみ，実際のワーディングを示す。

が魅力をもたらし，自席周りの狭さ，開放感のなさ，雑然とした 印象，打合せコーナ一不充足，レイアウト自由度がないこと，暑 さや寒さが不満をもたらしていると推察される。

Table4 Result of SEM [case2] (standardized path-coefficient)

X1 自席周り広さ:personal area

X3 会話しやすさ:conversation

X4 照明:lighting

X7 開放感:spaciousness

X8 室内整然:orderliness

X9 内装:interior

X14 打合せコーナー:meeting space

X17 レ仍外変更:layout change

X20 玄関ホール:entrance

X22 施設内移動:movement

X23 トイレ:toilet

X24 駐車場:parking area

X26 温熱感:thermal

X30 バリアフリー:barrier-free

X32 外観印象: exterior

$\chi^{2}=114.3(\mathrm{df}=59), \mathrm{RMSEA}=.040$ $\mathrm{CFI}=.990, \mathrm{GFI}=.981, \mathrm{SRMR}=.021$

Z35 魅力度: attractiveness

Z36 不満度: dissatisfaction

T37 働きやすい:good workplace

T38 総合満足: overall satisfaction T39 愛着:attachment

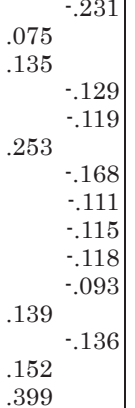

魅力 不満

\begin{tabular}{|rr}
.765 & \\
& .574 \\
.233 & -.654 \\
.396 & -.559
\end{tabular}

$.396-.559$ $.581-.135$
その他の項目に関して,「外観印象」が魅力要因であることは妥当 だが，「駐車場」「バリアフリー」が魅力要因であることはやや意外に 感じられる。建替え前の駐車場の不充足は職員にとって「仕方がない」 問題であり，新築等により改善されれば不満低減というより魅力を感 じるのかもしれない。バリアフリーに関して, 回答者の職員自身がバ リアフリー仕様を必要とする場合は少ないが，来庁者の中にはバリア フリー仕様が必要な方もいることであろう。そうした方々の利用状況 を目にしたり，訪問に対応した経験がある職員は，誰もが利用しやす いことを魅力要因と認識するのではないかと思う。このような魅力的 品質としての効用を示唆する結果は, バリアフリー推進のインセンテ イブにつながる可能性がある。この点は本事例の背景として論じた 「民間の範として誘導する役割」の観点から重要である。

その他, 不満要因となった項目に特段の違和感はないが, 「不満・ 不都合はない-ある」等の表現を用いている項目は不満へのパスが生じ やいということもあろう注 11)。「立関ホール」「トイレ」などは，ワー ディング注 ${ }^{12)}$ によっては魅力へのパスも生じるようにも思われる。

総合評価に対する魅力/不満の影響は項目により異なる。「働きやす い「総合満足」は事例 1 とは異なり, 魅力より不満の影響が大きい。 官庁施設職員の働きやすさにとっては「不満がないこと」が重要であ るらしい。民間企業のオフィスワーカー満足度調査を行った場合にも 同様であろうか。今後, 調查を試みたい。なお, 「愛着」は事例 1 と 同様，魅力からの影響が不満からよりかなり大きい。

また，本事例では，魅力-不満の間に直接的な関係は不要であった。 事例 1 に比べ，魅力と不満がより独立しているといえる。

\section{4 階層構造を導入した因果モデルの分析【事例 2】}

本事例においても事例 1 と同様，因果モデルに上位項目を追加する ことを試みたが，多くの上位項目を導入して解釈上有用なモデルを得 ることは困難であった。「自席周り総合評価」「室内雰囲気総合評価」 $\chi^{2=216.1(\mathrm{df}=211) \mathrm{p}=.390, \text { RMSEA }=.006}$ $\mathrm{CFI}=.999, \mathrm{GFI}=.968, \mathrm{SRMR}=.025$ 自席周り広さ: personal space area

\section{会話しやすさ: conversation} 照明: lighting 開放感開放感: spaciousness 室内整然: orderliness 内装: interior

その他の下位項目other items

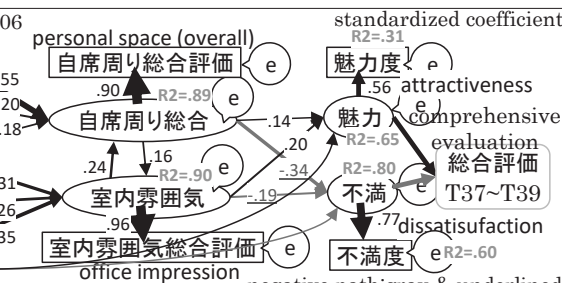

Fig.5 Causal model with hierarchical structure [case2]

の 2 つの上位項目を潜在変数化して導入した因果モデルを, これら項 目に関連しない項目を省略しつつ Fig.5に示す。適合度の点では「極 めて良好」であり, $\mathrm{p}$ 值基準で許容されるモデルである。

2 つの上位項目の潜在変数は魅力/不満の両方にパスを有すること から「一元的品質」である。両者は相互に影響し合う関係にあるため, 魅力/不満への総合効果は直接効果より大きくなり, 「自席周り総合」 からは魅力に.18, 不満に-.39,「室内䨌囲気」からは魅力に.24, 不満 に-.29 の標準化総合効果がある。ここで, これら上位項目を介した関 係として表現される下位項目から魅力/不満への影響は, 全てこの比と なる。つまり「自席周り広さ」「会話」「照明」から魅力/不満への影響 (絶対值) の比は， 3 項目とも魅力/不満=.18/.39 であり,「開放感」 「室内整然」「内装」からは魅力/不満=.24/.29 となる。いずれも一元 的品質となってしまうが，前節の分析結果によれば「会話」「照明」「内 装」は魅力的, 「自席周り広さ」「開放感」「室内整然」は当たり前品 質のはずである。下位項目ごとの魅力/不満への寄与の違いを表すため には魅力/不満に直接パスを設ければよいが，モデルが複雑化する。ま た，直接パスが多いようでは「階層性」の意味が乏しい (既報 $\left.{ }^{12}{ }^{2)}\right)$ 。

以上より，同じ上位項目の下位項目に「魅力的」「当たり前」「一元 的」が混在する場合, 階層性は設けない方がよい注 13) と思われる。

\section{7.「公園」に関するアンケート調査の分析【事例 3 】 7. 1 調査概要【事例 3】}

評価項目は分析結果とともにTable5に示す。項目設計においては, 塚田ほか 23)を参考に項目をリストアップし, 各項目について魅力と不 満のいずれの要因であるかを仮説提起, 魅力要因は魅力の度合いを答 える項目 $(\mathrm{P} 1 \sim 10)$, 不満要因は不満の度合いを答える項目 $(\mathrm{N} 11 \sim 21)$ としてワーディングしている。P1 と N11 (緑の状態), P8 と N14（清 潔感とゴミ）は同一ないし関連概念の不満側と魅力側を表す項目の組 
となる。個別評価に明確な階層構造は設定していない。個別評価と魅 力/不満度の選択肢は, 魅力/不満を「全く感じない(1)〜大いに感じる (5)」の 5 段階評価である。事例 2 で魅力/不満度の「ない」側の極を 「ほとんどない」と緩めた結果, 不満度の分散が過大となった反省か ら，「ない」側の極を「全くない」に戻している。

設問の順序は，まずいくつかの総合的印象とともに総合評価 (T24 25), 次に魅力に関する設問（P1 10,Z22），不満に関する設 問（N11 21,Z23）の順である。魅力/不満に関する設問の最後を（総 合的）魅力/不満度（Z22 23）としている。

\section{2 分析結果【事例 3】}

魅力/不満度の単純集計結果は,「ない」側から順に, 魅力度は $1.1 \%$. $8.9 \% \cdot 22.7 \% \cdot 46.0 \% \cdot 21.3 \%$ (平均=3.77, 標準偏差=.92), 不満度 は $15.3 \% \cdot 45.7 \% \cdot 26.5 \% \cdot 10.6 \% \cdot 1.8 \%$ (平均=2.37, 標準偏差=.93） となった。魅力のない・不満がある側の裾が長い分布であるが，分散 は適度であり, 天井・床効果の心配はない。相関係数は-.460 であっ た。他の事例より高相関であるが，問題視するほどではない。

本事例の評価対象公園の数は 2 個と少なく, 一方が主役で他方は比 較対象であることから, 両公園の因果構造を比較可能な多母集団同時 解析の SEM を適用する。パス図概形は Fig.3 と同様である。魅力/不 満から生じる全てのパスおよび「下位項目 $\rightarrow$ 不満」のパス係数は両公 園で有意差がないため等值制約をおき,「下位項目一魅力」のパス係 数は両公園に一部有意差があったため等值制約をおかないこととし た。適合度は良好であり $\mathrm{p}$ 值基準で許容されている。

Table5 の数值は, 魅力/不満と各項目の間の標準化パス係数注 ${ }^{14)}$ であ る。両公園のパス係数の差が有意（p<.05）な場合に下線を付した。 魅力/不満度の信頼性注 ${ }^{15}$ は は魅力度が.73, 不満度が.79 と推定される。 3 つめの事例にしてようやく良好な值となった。個別評価と魅力/不 満度の測定形式をあわせたことも信頼性良好の原因かもしれない。

\section{3 分析結果に基づく考察【事例 3】}

概ね仮説通りに魅力の個別評価は魅力に, 不満の個別評価は不満に 対して, 正の係数のパスが得られている。両公園で不満へのパスは等 值, 魅力へのパス係数には差があるモデルの適合がよいという結果は,

「不満要因は共通性が高く, 魅力要因は個別性が大きい」という個人 差に関する讃井 ${ }^{8)}$ の指摘が「環境差」に拡張できる可能性を示唆する。

両公園の差が大きい魅力要因に注目すると,まず「P10イベント」 は「浜名」のパスが有意に大きく、「佐鳴」はほぼ 0 (わずかに負だ が非有意）である。花博というイベントの跡地である「浜名」は，そ の後もイベント空間としての魅力を感 じさせているものと推察される。一方, 有意な差ではないが「浜名」より「佐鳴」 のパス係数が大きい魅力要因に「P4 交 流」「P5 自分の時間」がある。これら魅 力は生活の中に公園利用が定着した利 用者でないと感じにくく, 歴史の浅い 「浜名」における大きな魅力要因とはな っていないことが考えられる。

従って, 今後の「浜名」は, 花博跡地 としての特性を活かしてイベント等の 非日常空間としての魅力を維持しつつ,

「交流」「自分の時間」など日常に定着
した魅力づくりを考えるという指針が示唆される。その際，「佐鳴」 より魅力へのパスが有意に大きい「P 3 子供を遊ばせやすい」という 魅力に注目することも有効であろう注 16)。

次に,「魅力/不満一総合評価」のパス係数をみると, ほぼ魅力だけ が影響し，不満の影響は小さい。今までの利用で感じた不満が「わか っていれば対処可能」である場合には, 利用意向をさほど低めないの かもしれない。なお，魅力-不満の間の関係は，事例 1 と同様，魅力 は不満を低めるが，不満は魅力に影響しないというものであった。

\section{8. 総合的考察}

\section{1 魅力と不満の因子負荷量プロットおよび事例間比較}

潜在变数から観測変数への標準化パス係数を因子分析の用語を用 いて因子負荷量と呼ぶことがある。魅力/不満を因子とする総合評価の 因子負荷量プロットをFig. 6 に示寸。各事例の魅力/不満は異なるため 本来は事例ごとの図であるが，比較のため 1 つに重ねて示す。

全体的には，概㸚次のようである。

(魅力の影響大) $\leftarrow$ 公園一地域環境一官庁施設 $\rightarrow($ 不満の影響大)

ただし，官庁施設も「愛着」だけは魅力の影響が大きい。地域環境 においても「愛着」が最も魅力寄りであるから, これは様々な対象環 境において一般的にみられる傾向である可能性がある。

「愛着」以外の総合評価, 寸なわち居住や利用の意向・しやすさ・ 総合満足に関する上記の結果は, 選択の自由度や選択の機会の多さの 順序に対応しているとも考えられる。官庁施設の職員は職場環境に不 満があってもそこで働くしかない（転職しないとすれば）。居住地域 は選べるものの，現実的には様々な事情や制約があることだろう。公 園は行きたい公園を選べるし, 行かないこともできる。これら考察よ

Table5 Evaluation item and Result of SEM [case3: survey for the 2 parks] (standardized path-coefficient)

\begin{tabular}{|c|c|c|c|}
\hline 選択肢 choices & No 項目 (実際のワーディング): Item & $\begin{array}{r}\text { Result } \\
\text { (Hamana }\end{array}$ & $\begin{array}{l}\text { SEM } \\
\text { Sanaru) }\end{array}$ \\
\hline P1 Z23 & P1 木・草花・緑が多い:green richness & $.17 / .19$ & \\
\hline $\begin{array}{l}\cdots \text { いいう魅力/不満を } \\
1 \text { 全く感じない }\end{array}$ & P2 遊具がたくさんある: & - & - \\
\hline 2 あまり感じない & P3 子供を遊ばせやすい:suitable for kids & $.15 / .04$ & \\
\hline 3 どちらともいえない & P4 交流が生まれる:communication & $.02 / .13$ & \\
\hline 4 やや感じる & P5 自分の時間を持てる:private time & $.05 / .14$ & \\
\hline 5 大いに感じる & $\begin{array}{l}\mathrm{P} 6 \text { 様々な使い方（読書·散歩・昼寝…) } \\
\text { ができる:various usage }\end{array}$ & $.20 / .20$ & \\
\hline $\begin{array}{l}\text { T24 } \\
\text { 総合的に満足(5)-不満(1) }\end{array}$ & $\begin{array}{r}\text { P7 興味をひくものが多い: } \\
\text { something interesting }\end{array}$ & $.18 / .22$ & \\
\hline & P8 清潔感:がある:clean & $.09 / .18$ & \\
\hline また利用したい & P9 気軽に行ける:casual use & $.29 / .35$ & \\
\hline そう思う(5)-思 & P10イベントがたくさんある:event & $.14 /-.06$ & -.09 \\
\hline & $\begin{array}{r}\text { N11 木・草花・緑が整備されていない: } \\
\text { plant maintenance }\end{array}$ & & .11 \\
\hline & $\begin{array}{r}\text { N12 壊れたものが修理されていない: } \\
\text { broken things }\end{array}$ & & .16 \\
\hline $\begin{array}{l}\text { regional environment } \\
\text { case2:官庁施設 }\end{array}$ & N13 利用者マナー悪い:user manner & - & - \\
\hline pablic facilities & N14 ゴミが落ちている:garbage & - & - \\
\hline case3:1 & $\begin{array}{l}\text { N16 利用方法がわかりにくい施設・設 } \\
\text { N16 }\end{array}$ & & .16 \\
\hline & 備・遊具がある:easiness of use & - & - \\
\hline KW livability & N17 園内がわかりにくい:wayfinding & & .11 \\
\hline い preference & N18 まちなみ・景観に合っていない: & & .08 \\
\hline & N19 休憩施設が少ない:break space & & .15 \\
\hline $\begin{array}{l}\text { 総台浊足 } \\
\text { overall satisfaction }\end{array}$ & $\mathrm{N} 20$ 閉鎖的で入りにくい:unease of entering & $-.15 /-.14$ & .08 \\
\hline$\square$ 働きやすい & N21 柄の悪い人いる:evil likely person & & .24 \\
\hline $\begin{array}{l}\text { good } \\
\text { workplace }\end{array}$ & $\begin{array}{l}\chi^{2}=130.3(\mathrm{df}=112), \mathrm{p}=.114 \\
\text { RMSEA }=.014, \mathrm{CFI}=.998\end{array}$ & 1 & 不満 \\
\hline & Z22 魅力度:attractiveness & .791 & \\
\hline ion & $\begin{array}{l}\text { Z23 不満度: dissatisfaction } \\
\quad \text { (総合的に) この公園への魅力/不満 }\end{array}$ & & .848 \\
\hline & T24 総合満足:overall satisfaction & .723 & -.098 \\
\hline s and dissatisfac & |T25 利用意向:reuse intention & .739 & -.007 \\
\hline
\end{tabular}


り, 自由な選択ができないほど, (不満を感じつつ利用や居住が続く ため) 不満の影響が大きい, という仮説が得られる。また, 不満は経 験してから感じるものであるが, 魅力は選択の動機になる。よって, 選択の機会が多いほど魅力の影響が大きい，という仮説も得られる。

魅力-不満の間の関係に関して, 正式な学術用語ではないが, 魅力が 不満を下げる効果を指す言葉に「アバタもエクボ」「恋は盲目」「後光 効果」, 不満が魅力を下げる効果を指寸言葉に「坊主憎けりや袈泳ま で憎い」などがある。3つの事例のうち $2 つ （$ (地域と公園）に前者を 表す「魅力 $\rightarrow$ 不満」の負のパスが得られた。後者を表すパスはどの事 例でも生じていない。魅力は不満を下げる（隠す, マスクする, 等の 言い方もできそうである）場合はあるが，不満は魅力を下げないのだ ろうか。今後の課題として, この結果が一般的であるか調べたい。

また, 本手法では魅力が不満を下げる効果を「総合的な不満」への 効果とするが，その効果は個別評価レベルですでに生じているように も思われる。さらにあらゆる不満を下げるのではなく, 例えば「当た り前品質」の不満は下がらず「一元的品質」の不満は下がるというこ ともありそうである。これら仮説についても今後, 検討していきたい。

\section{2 潜在変数化した魅力/不満に関する 2 つの解釈}

潜在変数「魅力/不満」に関して, 次の 2 通りの解釈がありうる。 解釈 1 : 潜在変数「魅力/不満」は「魅力/不満度」の真值を表す。 解釈 2 : 個別評価から総合評価への影響を,「魅力度」だけに直接的 に影響する成分と,「不満度」だけに直接的に影響する成分に仕分け たものである。誤差はモデルにない個別評価からの影響を表す。

解䣋 1 の下では, 因果モデルは「人は環境評価する際, 魅力の大き さと不満の大きさをもとに総合評価を行っている」という意味に読め る。潜在変数を用いない 5.3 節のモデルも同様である。一方, 解釈 2 の下では,「人は実際には魅力/不満をもとに総合評価しているとは限 らないが，魅力/不満に仕分けた総合的評価を(求められれば) 評価可 能である」と, 魅力/不満の役割を緩めることができる。

本手法の意図に, “実際に”魅力/不満にわけて様々な認知や評価を 行っているという主張はない。当初アイディアである潜在変数のない 形の Fig.1 は, モデルの表す意味が強すぎた感がある。魅力/不満の潜 在変数化により，上記のように要件を緩めた解釈も可能となる。同時 に，評価者や環境によっては “実際に”魅力/不満にわけて評価する場 合もあると思うが，その状況も「解釈 1」として同じモデルが表現し うる。潜在変数化は, 単に適合度改善だけでなく, 要件緩和および可 能な解釈の幅という点でも有意義な方針である。

\section{3 調査分析の技法に関する考察}

最後に，各事例の調查分析結果をもとに技術的側面を考察する。

\section{1 ) 個別評価項目の設計}

個別評価項目の設計に関しては, 各項目が魅力と不満のどちらにつ ながるかを仮説として項目設計に反映させる事例 3 の方針と, 極力中 立的な測定形式とする事例 1 の方針がある。事例 2 のように一部の項 目だけ「不満・不都合がある-ない」等, 魅力か不満の一方に偏った口 ーディングとするよりは，仮説を反映する設計と中立的な設計のいず れかに舵を切る方が, 分析結果の考察段階で論の展開が明快になろう。 ただし仮説反映方式と中立設計方式で, どの程度結果が違うのかは不 明である。両者の比較を今後の課題としたい。

\section{2 ) 魅力/不満度の測定形式}

「魅力/不満度」の測定に関する結果は，事例 3 の「魅力/不満を，
大いに感じる一全く感じない」とう5 段階尺度が最も良好であった。 「感じる-感じない」「ある-ない」のどちらがよいかは未検討である。 中間のない 4 段階とした事例 1 では分散が小さかった。「どちらと もいえない」という中間点には批判的見解注 17 ももるが，実践的立場

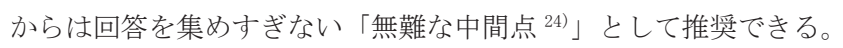

\section{3 ) 個別評価の階層化について}

事例 1 のように上位項目レベルで「魅力的」「当たり前」「一元的」 に分類でき, 各上位項目の要因となる下位項目も概秝その分類に該当 寸る場合は, 階層構造は有意義な考察をもたらす可能性がある。一方, 事例 2 のように 1 つの上位項目に影響寸る下位項目の中に「魅力的」 「当たり前」「一元的」が混在する場合, 階層構造は導入しにくい注 13$) 。$

いずれに該当する状況であるかを予見することは難しいかもしれ ない。本手法を適用寸る場合, 個別評価に階層性のないモデルを基本 と考え, 階層構造の導入は無理なく可能で有用な考察をもたらす場合 に限り適用するオプションと位置づけるのがよいであろう。

\section{4 ) 探索段階を含めた分析手順}

本手法の分析手順は次のようにするのがよいと思われる。 重回帰分析による予備的分析: 魅力/不満度と総合評価を目的变数, 個 別評価（および必要に応じて回答者や対象に関わる属性変数）を説明 変数候補としてステップワイズ式の重回帰分析を実行する。

SEM の初期モデル: Fig.3のように魅力/不満を表す潜在変数を用い, 総合評価には互いを結ぶ誤差相関と, 魅力/不満からのパスを設けたモ デルとする。個別評価には重回帰分析でいずれかの目的変数に対して 変数選択された項目を用い,「個別評価一魅力/不満」のパスを全て設 ける。魅力-不満の間にはひとまず誤差相関を設ける。

因果モデルの同定：不要なパス（符号が妥当でない，有意でない）を 適合度が低下しない範囲で削除していく。事前の仮説や重回帰分析の 結果から, 削除するパスの優先順位を考えてもよいと思われる。ある 程度パスの数が減った後, 魅力-不満の間を「魅力 $\rightarrow$ 不満」「不満 $\rightarrow$ 魅 力」等とするモデルも試行し, この部分の関係を決める。新たに不要 なパスが生じたらさらに削除し，採用するモデルを得る。

一見, 重回帰分析の通りに「個別評価 $\rightarrow$ 魅力/不満」のパスを設けれ ばよいように思われるが, 例えば事例 1 の「近所づきあい」「自然」「景 観」は, 重回帰分析と採用モデルでは魅力/不満とのつながり方が異な る (Table2, Fig.3)。魅力/不満の潜在変数化によりパス係数の希薄化 が修正され，検出力が高まった結果と思われる。また，重回帰で魅力 /不満度に対して選択されず総合評価に対して選択された個別評価は, SEM においては総合評価に影響する経路として魅力/不満へのパスを 確保すべきである。これら様々な状況を考えると, 重回帰分析の第一 の役割は因果モデル自体に用いる変数を選ぶことにとどめ, SEM に おいては「個別評価一魅力/不満」のパスが全てある初期モデルから探 索を始める方針を本報では推奨する。

\section{5 ）環境と評価者の抽出法について}

本報その 3 というより一連の「環境心理評価データの因果分析」研 究の論点となるが, 環境と評価者の抽出法により分析時の扱いが異な る部分がある。まず事例 1 のように観測個体ごとに環境と評価者の双 方が必ず異なる場合が通常の一般線形モデルの仮定に最も忠実な状 況である。事例 3 のように少数個の特定環境に対する調查の場合, 環 境ごとの多母集団同時解析が有用である。問題は事例 2 のように環境 の数が数十程度の場合である。環境ごとに異なる母集団として多母集 
団解析を行うには多すぎ，環境差と同一環境内個人差を同一視するに は少ないと思われる。本来は「マルチレベル SEM」を適用すべきで あるが，まだその適用方法論に未検討部分が多いため本報における適 用は見送った。マルチレベル SEM の適用法検討は今後の課題とした い。また別の観点として, 事例 2 の分析では環境毎の評価者数の不揃 いに対し, 評価者の多い環境に対寸る無作為再抽出という対応を行っ た。このようなきめ細かい事前処理は推奨されるものである。

\section{9. まとめ}

本論文の成果を 2 章で述べた目的に対応する形で総括する。 まず，「魅力」「不満」を中間変数として用いるという着想を提案し， 3 つの事例を用いて, 魅力と不満の要因および影響を把握可能である ことを示したことが第一の成果である。分析手法上の成果としては, 中間変数の潜在変数化, 重回帰分析による事前分析に始まるモデル探 索手順, 階層性の導入方法, 因子負荷量プロットによる魅力/不満の影 響分析法などに関わる知見を得た。魅力/不満に関わる評価構造につい ては, 各事例に関する狩野の品質分類に準じた考察, 魅力/不満の影響 の事例間の違いには選択の自由度や機会が関わるという考察 (今のと ころは仮説の提起に留まる) などの成果を得た。

本手法の測定部分は通常の CS 調查に 2 項目「魅力/不満度」を追加 するだけで済むことは大きな利点である。この利点を活かして適用事 例を増やし, 興味深い事例間比較を今後も行いたい。調查設計や測定 尺度に関する技術的課題もいくつか残されている。理論的側面として は, 本手法は魅力/不満を別概念とする点で狩野他 ${ }^{10)}$ より Herzberg ${ }^{9)}$ に近いが, 前者の要因効果の関数形に基づく品質分類との関係も検討 したい。これら課題に今後取り組む計画である。

\section{謝辞}

本報で提案する手法のアイディアの一部は著者 3 名を含む 6 名にて 特許出願（2005-020899）し, 現在は審査未請求による公知となって いる。事例 2 の調查は国交省営繥部の夕なさま, 事例 3 の調查は当時 早稲田大学人間科学部卒研生の飯田恭子氏, 石堂絵里香氏の尽力によ り実施された。関係各位に謝意を表します。

\section{付録}

中間変数の測定信頼性が低い場合に潜在変数化により適合度が改善されるし くみを補足説明しておく。

まず問題を単純化・一般化して, $\mathrm{X} \rightarrow \mathrm{Z} \rightarrow \mathrm{Y}$ という因果モデル $(「 \mathrm{X} \rightarrow \mathrm{Y} 」$ の因 果的影響が中間変数 Z を介した間接効果として説明される）を考える。しかし 変数に測定誤差があり, 真值を Xt, Yt,Zt で表すと, 因果関係は真值の間にある から, $\mathrm{Xt} \rightarrow \mathrm{Zt} \rightarrow \mathrm{Yt}$ が真のモデルである。 $\mathrm{Xt} \rightarrow \mathrm{Zt}$ および $\mathrm{Zt} \rightarrow \mathrm{Yt}$ の標準化パス倸 数を $\beta \mathrm{xz}, \beta$ zy とする。真值と測定値には, $\mathrm{X}=\mathrm{Xt}+\mathrm{e}_{\mathrm{x}}$ ( $\mathrm{e}_{\mathrm{x}}$ : 測定誤差) 等の関係が ある。測定信頼性は $\rho_{\mathrm{x}}=(\mathrm{Xt}$ の分散 $) /(\mathrm{X}$ の分散）等と定義される ( $\mathrm{Y}, \mathrm{Z}$ も同様)。

この真のモデルの下で得られる母相関係数行列と, 推定可能な 2 つのモデル をあてはめたときに得られる推定值を Table6 に示寸。

まず model-A $(\mathrm{X} \rightarrow \mathrm{Z} \rightarrow \mathrm{Y})$ の下では, $\mathrm{X}-\mathrm{Y}$ の相関係数として母相関の $\rho_{\mathrm{Z}}$ 倍の 值が推定される。つまり $\mathrm{Z}$ の信頼性 $\rho_{\mathrm{z}}$ が低くなるにつれ，母相関との乘離が大 きくなる。一方, X や Y の信頼性は母相関と推定相関の双方に同じ形で働き, 両者の乘離は招かない。よって, 原因 X や結果 $\mathrm{Y}$ の信頼性が低くとも適合度は 低下しないが, 中間変数 Z の信頼性が低いと適合度が低下寸ることがわかる。

そこで中間変数 Z の真值 Zt を潜在変数化した model-B を考える。相関係数 推定値は母相関と（期待值としては）一致し, 自由度 0 の飽和モデルとして必 ず識別できるモデルである。標準化パス係数 $\mathrm{b}_{\mathrm{xz}}, \mathrm{b}_{\mathrm{zy}}$ は $\mathrm{X}, \mathrm{Y}$ の信頼性平方根を乘 じた值が推定される。つまりパス係数の希薄化は生じている。しかしながらこ の点を技術的含意と寸れば，中間変数の潜在変数化は極めて有用といえる。

なお, model-B は 3 変数の原因に 1 因子をおく因子分析モデル $(X \rightarrow Z t$ のパ
スを逆向きにした形）と同值モデルであり，この因子分析モデルは不適解の可 能性はあるが必ず識別できる $\left(\right.$ 小島 $\left.{ }^{5}\right)$ )。同值モデルも同様である。

Table6 Reliability of intermediate variables and model fitting

\begin{tabular}{|c|c|c|c|c|c|c|}
\hline & path-diagram & parameter & \multicolumn{4}{|c|}{ correlation matrix } \\
\hline \multirow{2}{*}{$\begin{array}{l}\text { true } \\
\text { model } \\
\text { 真の } \\
\text { モデル }\end{array}$} & & \multirow{2}{*}{$\begin{array}{l}\text { standardized } \\
\text { coefficient } \\
\beta_{\mathrm{xz}} \\
\beta_{\mathrm{zy}} \\
\end{array}$} & & $\mathrm{X}$ & $\mathrm{Z}$ & $\mathrm{Y}$ \\
\hline & 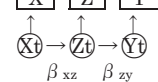 & & $\begin{array}{l}\mathrm{X} \\
\mathrm{Z} \\
\mathrm{Y}\end{array}$ & $\begin{array}{c}1 \\
\beta_{\mathrm{xz}} \sqrt{\left(\rho_{\mathrm{x}} \rho_{\mathrm{z}}\right)} \\
\beta_{\mathrm{xz}} \beta \underline{\mathrm{zy}} \sqrt{ }\left(\rho_{\mathrm{x}} \rho_{\mathrm{y}}\right) \\
\end{array}$ & $\begin{array}{c}1 \\
\left.\beta_{\mathrm{zy}} \sqrt{\left(\rho_{\mathrm{z}} \rho_{\mathrm{y}}\right.}\right) \\
\end{array}$ & 1 \\
\hline \multirow[b]{2}{*}{$\begin{array}{l}\text { model } \\
\text { A }\end{array}$} & & \multirow{2}{*}{$\begin{array}{l}\mathrm{b}_{\mathrm{xz}}= \\
\left.\beta_{\mathrm{xz}} \sqrt{(} \rho_{\mathrm{x}} \rho_{\mathrm{z}}\right) \\
\mathrm{b}_{\mathrm{zy}}= \\
\beta_{\mathrm{zy}} \sqrt{ }\left(\rho_{\mathrm{z}} \rho_{\mathrm{y}}\right)\end{array}$} & & $\mathrm{X}$ & $\mathrm{Z}$ & $\mathrm{Y}$ \\
\hline & 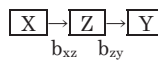 & & $\begin{array}{l}\bar{X} \\
Z \\
Y\end{array}$ & $\begin{array}{c}1 \\
\beta_{\mathrm{xz}} \sqrt{\left(\rho_{\mathrm{x}} \rho_{\mathrm{z}}\right)} \\
\beta_{\mathrm{xz}} \beta_{\mathrm{zy}} \rho_{\mathrm{z}} \sqrt{ }\left(\rho_{\mathrm{x}} \rho_{\mathrm{y}}\right)\end{array}$ & $\stackrel{1}{\beta_{\mathrm{zy}} \sqrt{ }\left(\rho_{\mathrm{z}} \rho_{\mathrm{y}}\right)}$ & 1 \\
\hline \multirow[b]{2}{*}{$\begin{array}{c}\text { model } \\
\mathrm{B}\end{array}$} & & \multirow{2}{*}{$\begin{array}{l}\mathrm{b}_{\mathrm{t}}=\sqrt{\rho_{\mathrm{z}}} \\
\mathrm{b}_{\mathrm{xz}}=\beta_{\mathrm{xz}} \sqrt{\rho_{\mathrm{x}}} \\
\mathrm{b}_{\mathrm{zy}}=\beta_{\mathrm{zy}} \sqrt{\mathrm{z}} \mathrm{\rho}\end{array}$} & & $\mathrm{X}$ & $\mathrm{Z}$ & $\mathrm{Y}$ \\
\hline & & & & $\begin{array}{c}1 \\
\beta_{\mathrm{xz}} \sqrt{\left(\rho_{\mathrm{x}} \rho_{\mathrm{z}}\right)} \\
\beta_{\mathrm{xz}} \underline{\beta z}_{\mathrm{zy}} \sqrt{ }\left(\rho_{\mathrm{x}} \rho_{\mathrm{y}}\right) \\
\end{array}$ & $\begin{array}{c}1 \\
\left.\beta_{\mathrm{zy}} \sqrt{\left(\rho_{\mathrm{z}} \rho_{\mathrm{y}}\right)}\right) \\
\end{array}$ & 1 \\
\hline
\end{tabular}

注

注 1）本報の基本的アイディアおよび事例 1 の分析は既報 ${ }^{12)}$ で報告済みである が分析・考察には修正を加えている。

注 2) 事例 1 の調査における別の設問としてデータを得たものである。

注 3）ここでは，利用や居住の経験がある対象に対する主観的な個別評価・総合 評価を回答するタイプの調査を指す。個別評価・総合評価のワーディングが 「満足度」ではない場合も含む。未経験の環境をその場で提示し評価を求め る調査にも適用可能ではあるが, 経験を通して実感される魅力/不満の代替 評価としうるか懸念されるため, 本報ではこの形の事例は検討対象としない 注 4）この目的に対する成果の一部は若林・小島 ${ }^{18)}$ にて報告している。

注 5）引用部分の（ ）内は本稿にて追記した補足である。

注 6）両公園周辺の 4 地域（町丁目）計 1254 世帯を対象に A4 版 6 頁の調查票を 全戸に郵送，有効 543 票 $(43.3 \%)$ を郵送回収した。さらに公園評価設問を 抜粋した A4 版 1 頁の調査票を 2008.10.11〜 12（土日）に「浜名」現地にて 公園利用者に直接配布する調查（配布 107 票・回収 103 票 (96.3\%) ) も実施 した。郵送調査は該当公園の利用経験者のみ回答する形式である。

注 7）既報 ${ }^{12)}$ の地域評価の下位項目は「不満の片側尺度」の形式であるが，分 析結果を参考に項目を整理しつつ満足側/不満足側に偏らない両極尺度のワ ーディングを考え, 武藤他 ${ }^{20)}$ の SD 尺度を参考にいくつかの上位項目を追加 している。総合評価はほぼ既報 ${ }^{12}$ をを踏襲している。

注 8）変数間の関係を誤差相関とすると, それら変数へのパス係数は「誤差相関 を設けた変数を介した間接効果」を(真の因果モデルにてその効果があれば) 含めた推定值となる。同レベル内の細かな因果関係より, 原因変数からの総 合的な因果効果に関心がある場合, 同レベルの変数に誤差相関を設ける方法 は誤モデル防止の安全策として有効である (小野・小島 ${ }^{21)}$ )。

注 9）「環境文化」「安全衛生」はまとまった概念とは感じにくいかもしれない。 これらのように, 観測変数に向からパスより観測変数から受けるパスが多い 潜在変数を「結果指標」と呼ぶことがある（因子分析モデルのように，いく つかの観測変数の原因変数として同定される潜在変数は「原因指標」である) 結果指標の因果モデル上の主要な役割は, より結果系の変数に対して同じよ うな影響を与える観測変数からの影響成分をまとめるものであり, 誤差変数 が加わる前は「合成変数」である。結果系への影響が似ていれば, 因子分析 的には同一概念とならない影響成分が 1 つの「結果指標」を形成する場合が ある。本モデルにおける「環境文化」「安全衛生」は, 必ずしも因子分析的 な意味における 1 つの潜在因子の存在を主張するものでなく, 複合的な概念 が集約されている可能性がある。変数の命名には苦慮したが, 違和感を感じ る方は「環境文化（=生活環境と文化的生活）」「安全衛生（=安全と衛生）」 の複合概念，あるいは結果系変数一の影響構造から，前者を「魅力的因子」， 後者を「当たり前因子」と読夕替えていただきたい。

注 10）評価構造ではなく地域特性がつくる相関関係とするのが妥当と考える。

注 11）魅力要因となった「照明」「駐車場」もこの表現であるから, ワーディン グだけが不満へのパスを誘導しているとは考えにくい。

注 12）一般的な「不満-満足」という評価，あるいは「きれい」「使いやすい」 等のポジティブ側の表現を用いたワーディングなどが考えられる。

注 13）これは「階層性を設けた因果モデルは評価構造の理解・実証の点で有用 である」という既報 ${ }^{12)}$ の主張を否定するものではない。魅力と不満の要因・ 影響分析のためには階層性を設けないモデル, 階層構造把握のためには階層 性を設けた（魅力や不満は用いない）モデルと, 目的により因果モデルを使 い分けるのがよいということである。

注 14）多母集団解析の場合, 母集団ごとに異なる分散を用いて標準化した結果 を示すと分散が違うのか係数が違うのか区別できない。そこでここでは両公 園とも「浜名」の母分散推定值を用いて標準化したパス係数を示している。 
注 15）両公園の平均の違いも含む全体の母分散推定值（魅力度. 85/不満度. 87） と, 等值制約した誤差分散推定值 (魅力度. 23/不満度. 19) から求めている 注 16）考察は調査実施時点のものであり，現在はまた異なる状況と思われる。 調査分析結果は, 当時公園管理センターに報告していることを附記する。

注 17） 1 つの概念の程度を答える尺度の場合, 評価可能ならば「どちらともい えない」はずはなく，中間点には「ほどほど」「中程度」「普通」を意味する 言葉を使うべきという見解がある。しかし例えば「普通」は，多くの場合に 該当する状況をそう呼ぶのであるから回答が集まりやすい傾向がある（従つ て, 分散を小さく寸る)。プラグマティックな立場からは「どちらともいえ ない」は回答を集めすぎない中間点として「無難なスタンダード」である（文 献 ${ }^{24)}$ 参照：主な関連部分は pp. 60-61)

\section{参考文献}

1) Kojima,T et al: A STUDY ON THE HIERARCHICAL STRUCTURE OF EVALUATION USING "GRAPHICAL MODELING" -Causality analysis on environmental evaluation Part 1-, Journal of Structural and Construction Engineering (Transactions of AIJ), No.535, pp.47-52, 2000.9 (in Japanese) 小島隆矢・若林直子ほか：グラフィカルモデリングによる評価の階層性の検討 環境心理評価構造における統計的因果分析 その $1-$, 日本建築学会計画系論文集, No. 535 , pp. $47-52,2000.9$

2) Kojima,T et al.: EXPLORATORY MODELING FOR CAUSALITY IN HIERARCHICAL STRUCTURE OF EVALUATION -Causality analysis on environmental evaluation Part 2-, Journal of Structural and Construction Engineering (Transactions of AIJ), No.556, pp.77-82, 2002.6 (in Japanese)

小島隆矢・若林直子ほか：階層的評価構造における因果関係の探索的モデリング -環境心理評価構造における統計的因果分析 その 2-, 日本建築学会計画系論文集, No. 556 , pp. $77-82,2002.6$

3) Sanui,J and Inui,M.: PHENOMENOLOGICAL APPROACH TO THE EVALUATION OF PLACES, Journal of Structural and Construction Engineering (Transactions of AIJ), No.367, pp.15-22, 1986.9 (in Japanese) 讃井純一郎・乾正雄：レパートリー・グリッド発展手法による住環境評価構造 の抽出, 日本建築学会計画系論文報告集, No. 367, pp. 15-22, 1986.9 4) Sanui,J and Inui,M.:SUBGROUPING APPROACH TO THE STRUCTURAL MODEL OF PLACE EVALUATION, Journal of Structural and Construction Engineering (Transactions of AIJ), No.374, pp.54-59, 1987.4 (in Japanese) 讃井純一郎・乾正雄：個人差及び階層性を考慮した住環境評価構造のモデル化, 日本建築学会計画系論文報告集, No. 374, pp. 54-59, 1987.4

5) Kojima,T: Excel de manabu SEM \& GM, Ohmsha, 2003.12 (in Japanese) 小島隆矢：Excel で学ぶ共分散構造分析とグラフィカルモデリング, オーム 社, 2003. 12

6) Canter,D:The purposive evaluation of places, Environment and Behavior, Vol.15,No.6, Sage:BeverlyHills. 1983

7) Kuno,S: Kyojuukankyohyouka ni kansuru kenkyuu, Doctoral thesis, Univ. of Tokyo, 1980 (in Japanese)

久野覚：居住環境評価に関する研究, 東京大学学位論文, 1980

8) Sanui,J: Interview Research for Product Planning : Present Status and Issues to be Solved, Quality (Journal of JSQC), Vol.33, No.3, pp.281-288, 2003.7 (in Japanese)

讃井純一郎：商品企画のためのインタビュー調査: 従来型インタビュー調査と 評価グリッド法の現状と課題, 品質, Vol. 33, No. 3, pp. 281-288, 2003.7

9) Herzberg,F: WORK AND THE NATURE OF MAN,1966 (北野利信訳：仕事と人間性：東洋経済新報社：1968.2)

10) Kano,N et al:: Attractive Quality and Must-Be Quality, Quality (Journal of JSQC), Vol.14, No.2, pp.147-156, 1984.4 (in Japanese)

狩野紀昭ほか：魅力的品質と当り前品質，品質，Vol. 14, No. 2, pp. 147-156, 1984. 4 11) Kitagaki,T: An examination into Herzberg's research : To achieve an effective method for making someone motivated,Oikonomika, Vol.48, No.2, pp.43-59, 2012.2 (in Japanese)

北垣武文: ハーズバーグの研究方法に関する一考察, オイコノミカ, Vol. 48, No. 2, pp. 43-59, 2012. 2

12) Koga,T et al.: PARTICIPATORY RESEARCH OF TOWNSCAPE, USING "CAPTION EVALUATION METHOD", Journal of Structural and Construction Engineering (Transactions of AIJ), No.517, pp.79-84, 1999.3 (in Japanese) 古賀誉章・高明彦・宗方淳・小島隆矢ほか：キャプション評価法による市民参 加型景観調査, 日本建築学会計画系論文集, No. 517, pp. 79-84, 1999.3

13) Kojima,T and Wakabayashi,N: Methodology of the questionnaire about living environment Part 2, Summaries of Technical Papers of Annual Meeting, Architectural Institute of Japan, D-1, pp.891-892, 2004.7 (in Japanese) 小島隆矢・若林直子：地域環境に関寸る意識調查手法の研究 その 2 地域に対 する不満と魅力の捉え方, 日本建築学会大会学術講演梗概集, D-1, pp. 891-892, 2004. 7

14) Taka,A et al.: A Study on the Quality of Environment Evaluation Item, Summaries of Technical Papers of Annual Meeting, Architectural Institute of Japan, D-1, pp.727-728, 1997.7 (in Japanese)

高昭彦・小島隆矢ほか：環境評価項目の表す「品質」に関する一考察，日本建 築学会大会学術講演梗概集, D-1, pp. 727-728, 1997.7

15) Kojima,T et al.: THE METHOD OF RESEARCH AND ANALYSIS, USING "INDIVIDUAL SCALES" -Studies on the environmental evaluation by subjects' own term Part 1-, Journal of Structural and Construction Engineering (Transactions of AIJ), No.525, pp.91-96, 1999.11 (in Japanese)

小島隆矢・川井敬二・平手小太郎・安岡正人：個別尺度を用いた調査・分析法 の提案 一評定者自身の言葉による環境評価に関寸る研究 その $1-$, 日本建築学 会計画系論文集, No. 525, pp.91-96, 1999.11

16) Peng Bo and Kojima,T: A COMPARABLE INTERPRETABILITY STUDY BETWEEN EVALUATION GRID METHOD,REPERTORY GRID METHOD AND TYPICAL FREE DESCRIPTION :A study on qualitative research for getting evaluation term, Journal of Environ. Eng. (Transactions of AIJ), Vol.81, No.726, pp.661-668, 2016.8 (in Japanese)

彭博・小島隆矢：評価グリッド法・レパートリーグリッド法・定型自由記述の説 明力比較, 日本建築学会環境系論文集, Vol.81, No. 726, pp. 661-668, 2016.8

17) Kojima,T: Attructive quality and Must-be quality, PUBLIC BUILDINGS, Vol.51-2， No.197， pp.80-83, 2009.10 (in Japanese)

小島隆矢：魅力的品質と当たり前品質，公共建築，Vol. 51-2, No. 197, pp. 80-83, 2009. 10

18) Wakabayashi,N and Kojima,T: Methodology of the questionnaire about living environment Part1, Summaries of Technical Papers of Annual Meeting, Architectural Institute of Japan, D-1, pp.889-890, 2004.7 (in Japanese)

若林直子・小島隆矢：地域環境に関する意識調査手法の研究 その 1 地域との 関わり方をを捉える項目に関する検討, 日本建築学会大会学術講演梗概集,

D-1, pp. 889-890, 2004.7

19) Kojima,T et al.: A Study on Customer Satisfaction at Public Buildings Part2, CS-Survey in Post-Occupancy Phase, Summaries of Technical Papers of Annual Meeting, Architectural Institute of Japan, D-1, pp.839-840, 2006.7 (in Japanese) 小島隆矢ほか：公共施設における顧客満足度向上に関寸る取り組み その 2 入居後 の顧客満足度調査, 日本建築学会大会学術講演梗概集, D-1, pp. 839-840, 2006.7 20) Muto,H et al.:A STUDY ON THE RELATION BETWEEN HOW CITIES ARE EVALUATED AS A WHOLE AND HOW CITY ELEMENTS ARE POINTED OUT ON MAPS, Journal of Environ. Eng. (Transactions of AIJ), No.594, pp.53-59, 2005.8 (in Japanese)

武藤秀明・尹在男ほか: まち全体の評価と個別の都市要素の地図指摘との関連 についての研究, 日本建築学会環境系論文集, No. 594, pp. 53-59, 2005. 8

21) Ono,K and Kojima,T: The Estimation of Causality Effect of each item based on CS-Survey data, Summaries of Technical Papers of Annual Meeting, Architectural Institute of Japan, D-1, pp.49-50, 2008.7 (in Japanese)

小野久美子・小島隆矢：CS 調査データに基づく項目重要度の算出法, 日本建築 学会大会学術講演梗概集, D-1, pp. 49-50, 2008.7

22) Wakabayashi,N et al.: A Survey of Attraction and Value of Residence from the Viewpoint of City dwellers -Part 2 Proposal of "Five places" that City dwellers needs-, Summaries of Technical Papers of Annual Meeting, Architectural Institute of Japan, D-1, pp.39-40, 2010.9 (in Japanese) 若林直子ほか: 都市生活者の視点からみた地域の魅力・価值に関する研究 そ の 2, 日本建築学会大会学術講演梗概集, D-1, pp. 39-40, 2010.9

23) Tsukada,S et al.: A Study of the Evaluation Structure and Attractive Factions of Large-scale Park caught from User's Consciousness, Journal of the City Planning Institute of Japan, No.39, pp.193-198, 2004.11(in Japanese) 塚田伸也ほか：大公園における利用者の評価構造に関する検討 -前橋市の総 合公園を事例として一，都市計画論文集，No. 39，pp. 193-198, 2004.11

24) AIJ(Ed.): Design of research for housing and city planning, Ohmsha, 2011.3 (in Japanese)

日本建築学会編：住まいと街をつくるための 調査のデザイン，オーム社，2011.3 


\title{
CAUSAL MODEL FOR ANALYZING CAUSES AND EFFECTS \\ OF ATTRACTIVENESS AND DISSATISFACTION
}

- Causality analysis on environmental evaluation Part 3 -

\author{
Takaya KOJIMA* , Naoko WAKABAYASHI ** and Junichiro SANUI*** \\ * Prof., Faculty of Human Sciences, Waseda University, Dr. Eng. \\ ** Representative Director, Living environment studio act, Dr. Eng. \\ *** Prof., College of Interhuman Symbiotic Studies, Kanto Gakuin University, Dr. Eng.
}

\section{Background and objective}

This study examines the methodology of Causality analysis on environmental evaluation. The purpose of this paper is to propose a new method to grasp causes and effects of "attractiveness(subjective satisfaction)" and "dissatisfaction" based on environmental evaluation data.

\section{Basic idea}

First, it is necessary to conduct a survey that respondents evaluate the environment using the following three kinds of evaluation items: i) Evaluation items of each viewpoint (several to dozen), ii) Evaluation of "attractiveness" and "dissatisfaction" (2 items), iii) Comprehensive evaluations (1 or more items).

Then, the following causal model is applied to the obtained evaluation data:

\{Cause variables: evaluation items of each viewpoint\} $\rightarrow$ \{Intermediate variables: "attractiveness" and "dissatisfaction" $\} \rightarrow$ \{Result variables: comprehensive evaluations\}

Based on the obtained causal model, causal effects from "attractiveness" and "dissatisfaction" to comprehensive evaluations are grasped. And cause variables are classified using Kano model as follows.

"Attractive Quality": Items that have effect to "attractiveness" and no effect to "dissatisfaction".

"One-dimensional Quality": Items that have effect to both "attractiveness" and "dissatisfaction".

"Must-be Quality": Items that have effect to "dissatisfaction" and no effect to "attractiveness".

\section{Case study}

In order to examine more concrete survey and analysis methods, analysis based on the proposed method was applied to the following three survey cases. Case1: survey for regional environment, Case2: CS-survey for pablic facilities, Case3: survey for large-scale park.

\section{Findings}

The most important outcome of this research is that we were able to show that it is possible to grasp the cause and effect of "attractiveness" and "dissatisfaction" based on evaluation data of case study survey.

Furthermore, the following findings regarding methodology and evaluation mechanism were obtained.

As the first step of analysis, how to apply multiple regression analysis to select variables used for analysis was proposed. As the next step, moodel building process in SEM was proposed.

The effectiveness and significance of the technique using intermediate variables "attractiveness" and "dissatisfaction" as latent variables was discussed. This technique has the significance of preventing deterioration of goodness of fit due to poor reliability of "attractiveness" and "dissatisfaction", and the significance of relaxing the assumption required for the actual evaluation structure represented by the model.

It was shown that causal model with hierarchical structure is sometimes useful, sometimes not useful. The latter case is when Must-be Quality items and Attractive Quality items coexist in lower level items affecting the same upper level items.

As a visualization of the effects of "attractiveness" and "dissatisfaction", factor loading plot of "attractiveness" and "dissatisfaction" was proposed. This graph is also useful for comparison between cases.

\section{Future tasks and prospects}

The future tasks are to apply the proposed method to many cases, and to reconsider relationship between the proposed method and the Kano model (The item classification by the Kano model is defined by function form of causal effect to result variable.). 